\title{
PENGARUH RASIO LIKUIDITAS, LEVERAGE DAN AKTIVITAS TERHADAP PERTUMBUHAN LABA PERUSAHAAN MAKANAN DAN MINUMAN DI BEI
}

\author{
RUDIKSON \\ MUSLIMIN \\ FAISAL \\ Program Studi S1 Manajemen Fakultas Ekonomi Universitas Tadulako \\ email: kakakson18@gmail.com
}

\begin{abstract}
ABSRACT
It cannot be denied that profit growthcannot be separated from the financial peformance of the company which is reflected in the financial ratios. The objective of this research is to examine the effect of liquidity, Leverage and activity both simultaneusly and partially to profit growth of food and beverage company listed on the Indonesia Stock Exchange period of 2012 to 2016. The sample was 11 food and beverage companies listed on Indonesia Stock Exchange. The financial ratio used liquidity(curent ratio), Leverage (debt to equity ratio) and activity (total asset turn over). The data were analyzed throgh multiple linear regression analysis. Based on the result of $F$ test shows that the value of sig <0,05, so it can be concluded that the financial ritios consist of liquidity, Leverage and activity simultaneously effect to profit growth. The result of t test shows that independent variable of liquidit5 and activity partially have no significant effect to proffit growth because value of sig > 0,05 while the independent variable of Leverage partially effect to profit growth because the value of sig $<0,05$.
\end{abstract}

Keywords: Liquidity, Leverage, Activity, Profit Growth

\section{ABSTRAK}

Tidak dapat dipungkiri bahwa pertumbuhan laba tidak bisa terlepas dari kinerja keuangan perusahaan yang tercermin dalam rasio-rasio keuangan. Penelitian ini bertujuan untuk menguji pengaruh likuiditas, Leverage dan aktivitas baik secara simultan maupun parsial terhadap pertumbuhan laba perusahaan makanan dan minuman yang terdaftar di Bursa Efek Indonesia periode 2012-2016. Sampel penelitian ini adalah 11 perusahaan makanan dan minuman yang terdaftar di Bursa Efek Indonesia. Rasio keuangan yang digunakan adalah likuiditas (current ratio), Leverage (debt to equity ratio) dan aktivitas (total asset turn over). Teknik analisis yang digunakan adalah analisis regresi linier berganda. Berdasarkan hasil uji $\mathrm{F}$ diketahui bahwa nilai sig $<0,05$ sehingga dapat diambil simpulan bahwa rasio keuangan yang terdiri atas likuiditas, Leverage dan aktivitas secara simultan berpengaruh terhadap pertumbuhan laba. Berdasarkan hasil uji t diketahui bahwa variabel bebas likuiditas dan aktivitas secara parsial tidak berpengaruh signifikan terhadap pertumbuhan laba karena nilai sig > 0,05. Sedangkan variabel bebas Leverage secara parsial berpengaruh terhadap pertumbuhan laba karena nilai sig $<0,05$.

Kata kunci: Likuiditas, Leverage, Aktivitas, Pertumbuhan Laba

\section{PENDAHULUAN}

Salah satu masalah pokok yang dihadapi dalam masa pembangunan sekarang ini adalah menjamin kesinambungan pembangunan nasional yaitu dengan mengusahakan tersedianya dana bagi pembangunan. Secara garis besar pembangunan nasional memang menghendaki tersedianya dana untuk pembangunan dalam jumlah yang memadai. Oleh karena itu harus diupayakan pengadaan sumber-sumber dana dalam negeri guna meningkatkan kemandirian suatu negara.

Pasar modal merupakan salah satu dari berbagai sarana yang ada untuk mendapatkan modal bagi perusahaan didalam kegiatan usahanya. Salah satu syarat bagi perusahaan tersebut untuk mendapatkan modal adalah perusahaan tersebut harus sudah go public. Perusahaan makanan dan minuman 


\section{Rudikson}

merupakan salah satu kategori sektor industri di Bursa Efek Indonesia (BEI) yang mempunyai peluang untuk tumbuh dan berkembang.

Secara garis besar, saat ini dalam praktik setidaknya ada lima jenis rasio keuangan yang sering di gunakan yaitu rasio likuiditas, rasio Leverage atau solvabilitas, rasio aktvitas, rasio profitabilitas dan rasio penilaian atau rasio ukuran pasar (Hery, 2016:142). Penelitian ini menggunakan tiga rasio untuk mengukur pengaruhnya terhadap pertumbuhan laba perusahaan, yaitu rasio likuiditas, Leverage dan aktivitas.

Rasio likuiditas adalah rasio yang digunakan untuk menunjukan kemampuan perusahaan dalam melunasi utang jangka pendeknya. Jika perusahaan memiliki kemampuan membayar atau melunasi utang jangka pendeknya saat jatuh tempo maka dapat dikatakan perusahaan tersebut merupakan perusahaan yang likuid. Jenis rasio likuiditas yang digunakan dalam penelitian ini adalah rasio lancar (curent ratio). Rasio lancar (curent ratio) merupakan rasio yang menggambarkan seberapa besar ketersediaan aset lancar dalam perusahaan dibandingkan dengan kewajiban atau hutang lancar. Rasio lancar dihitung sebagai hasil bagi total aset lancar dengan total kewajiban/utang lacar, Kasmir (2015:13).

Rasio Leverage atau rasio solvabilitas merupakan rasio yang digunakan untuk mengukur sejauh mana aktiva perusahaan dibiayai oleh hutang. Ukuran rasio Leverage yang digunakan dalam penelitian ini adalah Debt to Equity Ratio(DER). DER digunakan untuk menilai utang dengan ekuitas atau dengan kata lain rasio ini berguna untuk mengetahui jumlah dana yang disediakan peminjam (kreditur) dengan pemilik perusahaan (Kasmir, 2015:151).

Rasio aktivitas menggambarkan aktivitas yang dilakukan perusahaan dalam menjalankan operasinya baik dalam kegiatan penjualan, pembelian dan kegiatan lainnya. Penelitian ini jenis rasio aktivitas yang digunakan adalah Total Assets Turn Over (TATO). Rasio ini merupakan rasio yang digunakan untuk mengukur keefektifan total aset yang dimiliki perusahaan dalam menghasilkan penjualan atau dengan kata lain untuk mengukur seberapa jumlah penjualan yang akan dihasilkan dari setiap Rupiah dana yang tertanam dalam total aset. Perputaran total aset yang rendah menandakan perusahaan belum maksimal dalam menciptakan penjualan dan meghasilkan laba (Hery, 2016:187).

\section{KAJIAN LITERATUR DAN PENGEMBANGAN HIPOTESIS}

1. Secara simultan Likuiditas Leverage dan Aktivitas berpengaruh signifikan terhadap Pertumbuhan Laba pada perusahaan makanan dan minuman yang terdaftar di Bursa Efek Indonesia.

2. Likuiditas berpengaruh positif dan signifikan terhadap Pertumbuhan Laba pada perusahaan makanan dan minuman yang terdaftar di Bursa Efek Indonesia.

3. Leverage berpengaruh positif dan signifikan terhadap Pertumbuhan Laba pada perusahaan makanan dan minuman yang terdaftar di Bursa Efek Indonesia.

4. Aktivitas berpengaruh positif dan signifikan terhadap Pertumbuhan Laba pada perusahaan makanan dan minuman yang terdaftar di Bursa Efek Indonesia.

\section{Rasio Keuangan}

Rasio keuangan adalah kegiatan membandingkan angka-angka yang ada dalam laporan keuangan dengan membagi satu angka dengan angka lainmya (kasmir, 2015:104). Hery (2016:138) rasio keuangan merupakan suatu perhitungan rasio dengan menggunakan laporan keuangan yang berfungsi sebagai alat ukur dalam menilai kondisi keuangan dan kinerja perusahaan.

\section{Rasio Likuiditas}

Sutrisno (2013:222) likuiditas adalah kemampuan perusahaan untuk membayar kewajibankewajibannya yang segera harus dipenuhi. Kewajiban yang harus dipenuhi adalah hutang jangka pendek, oleh karena itu rasio ini dapat digunakan untuk mengukur tingkat keamanan kreditor jangka pendek. Jenis rasio likuiditas yang digunakan dalam penelitian ini adalah rasio lancar (curent ratio). 
Rasio lancar (curent ratio) merupakan rasio yang menggambarkan seberapa besar ketersediaan aset lancar dalam perusahaan dibandingkan dengan kewajiban atau hutang lancar. Rasio lancar dihitung sebagai hasil bagi total aset lancar dengan total kewajiban/utang lacar, Kasmir (2015:13).

\section{Rasio Leverage}

Hery (2016:162) Rasio Leverage atau rasio solvabilitas merupakan rasio yang digunakan untuk mengukur sejauh mana aset perusahaan dibiayai oleh hutang. Rasio solvabilitas atau Leverage digunakan untuk mengukur kemampuan perusahaan dalam memenuhi seluruh kewajibannya, baik kewajiban jangka pendek maupun jangka panjangnya. Jenis rasio Leverage yang digunakan adalah debt to equity. Kasmir (2015:157) mengartikan bahwa debt to equity ratio adalah rasio yang digunakan untuk menilai utang dengan ekuitas (modal).

\section{Rasio Aktivitas}

Rasio aktivitas ini mengukur seberapa besar efektivitas perusahaan dalam memanfaatkan sumber dananya. Rasio aktivitas dinyatakan sebagai perbandingan penjualan dengan berbagai elemen aktiva (Sutrisno, 2013:226). Kasmir (2015:172) mendefinisikan bahwa rasio aktivitas merupakan rasio yang digunakan untuk mengukur efektivitas perusahaan dalam menggunakan aktiva yang dimilikinya. Berdasarkan berbagai jenis rasio aktivitas di atas, pada penelitian ini jenis rasio aktivitas yang digunakan adalah perputaran total aktiva (Total Asset Turn Over). Kasmir (2015:185) total asset turn over merupakan rasio yang digunakan untuk mengukur perputaran semua aktiva yang dimiliki perusahaan dan mengukur berapa jumlah penjualan yang diperoleh dari tiap rupiah aktiva.

\section{Pertumbuhan Laba}

Laba sebagai suatu alat prediktif yang membantu dalam peramalan laba mendatang dan peristiwa ekonomi yang akan datang. Laba yang digunakan dalam penelitian ini adalah laba setelah pajak (Earning After Tax), Pertumbuhan laba dihitung dengan cara mengurangkan laba periode sekarang dengan laba periode sebelumnya kemudian dibagi dengan laba pada periode sebelumnya Warsidi dan Pramuka (2000).

\section{METODE PENELITIAN}

\section{Jenis Penelitian}

Penelitian ini adalah adalah penelitian Deskriptif verifikatif yang bertujuan untuk menjelaskan suatu fenomena empiris yang disertai data statistik, karakteristik dan pola hubungan antar variabel yang dapat diketahui hubungan variabel dependen terhadap variabel independen dengan menggunakan alat analisis regresi linear berganda. Penelitian ini difokuskan pada rasio-rasio yang diduga dapat mempengaruhi pertumbuhan laba suatu perusahaan yang di mana rasio-rasio tersebut adalah likuiditas yang dalam penelitian ini digunakan rasio lancar (curent ratio), Leverage menggunakan rasio modal terhadap utang (debt to equity ratio) dan aktivitas mengunakan rasio perputaran total aktiva (total asset turn over).

\section{Lokasi Dan Waktu Penelitian}

Penelitian ini dilakukan pada perusahaan makanan dan minuman yang terdaftar pada Bursa Efek Indonesia dengan menggunakan periode waktu yaitu tahun 2012 sampai dengan 2016. Penelitian ini dilakukan dengan cara pengambilan data melalui situs web yang disediakan oleh Bursa Efek Indonesia (www.idx.co.id), guna untuk melengkapi data yang diperlukan oleh peneliti.

\section{Metode Pengumpulan Data}

Pengumpulan data dilakukan dengan menggunakan metode dokumentasi, yaitu pengambilan atau pengumpulan dokumen-dokumen laporan keuangan tahunan perusahaan makanan dan minuman di Bursa Efek Indonesia periode 2012-2016. Sugiyono (2013:240) dokumentasi merupakan catatan 


\section{Rudikson}

peristiwa yang sudah berlalu. Dokumen bisa berbentuk tulisan, gambar, atau karya-karya monumental dari seorang. Dokumen yang berbentuk tulisan misalnya catatan harian, sejarah kehidupan (life histories), ceritera, biografi, peraturan, kebijakan.

\section{Analisis linear berganda}

Untuk menguji hipotesis yang telah ditentukan maka teknik analisis yang digunakan adalah analisis regresi linear berganda. Alat analisis yang digunakan untuk mengetahui pengaruh variabel likuiditas, Leverage dan aktivitas terhadap pertumbuhan laba perusahaan makanan dan minuman yang terdaftar di Bursa Efek Indonesia. Menurut Indriantoro dan Supomo (2009:211) analisis regresi berganda digunakan untuk menguji pengaruh dua atau lebih variabel independen terhadap variabel dependen dengan skala pengukuran interval atau rasio dalam suatu persamaan linear. Rumus dari regresi linear berganda yaitu:

\section{HASIL DAN PEMBAHASAN}

\section{Uji Normalitas Data}

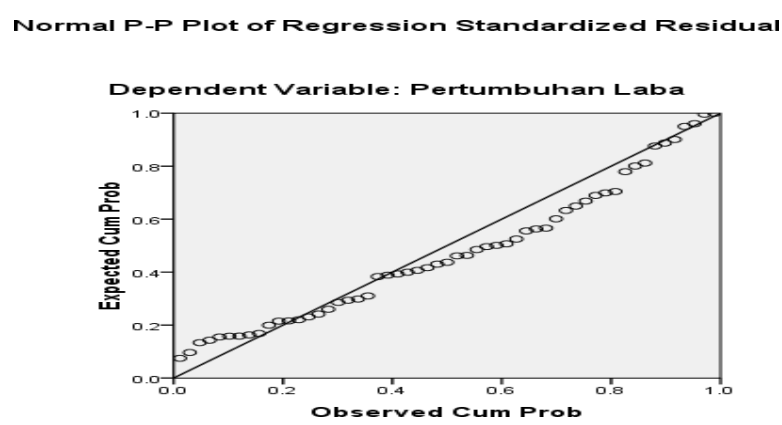

Gambar 1

Model regresi yang baik adalah distribusi data normal atau mendekati normal (Santoso, 2000). Deteksi normalitas dilakukan dengan melihat penyebaran data (titik) pada sumbu diagonal dari grafik. Berdasarkan Gambar 1 dapat diketahui bahwa titik-titik menyebar di sekitar garis diagonal dan penyebarannya mengikuti arah garis diagonal, dengan demikian Dapat dinyatakan bahwa penyebaran data memenuhi normalitas.

\section{Uji Heteroskedastisitas}

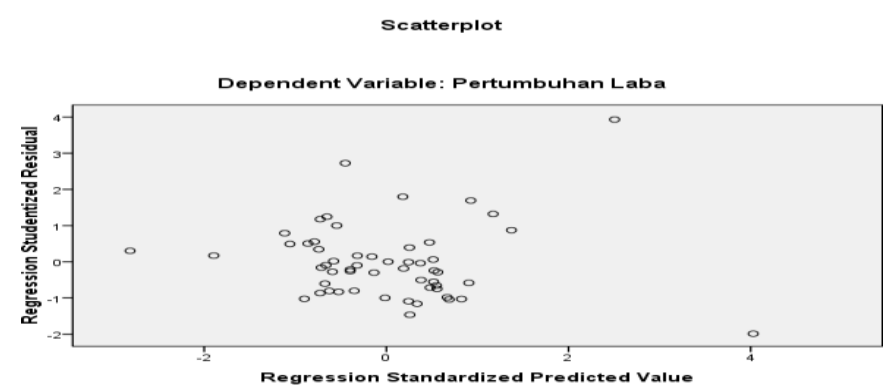

Gambar 2

Untuk mendeteksi ada tidaknya heteroskedastisitas dalam model regresi bisa dilihat dari pola yang terbentuk pada titik-titik yang terdapat pada grafik scaterplot. Berdasarkan Gambar 2, dapat dilihat bahwa titik- itik menyebar di atas dan di bawah angka nol pada sumbu Y, maka dapat disimpukan bahwa tidak terjadi heteroskedsatisitas.

\section{Uji Autokorelasi}


Tabel 1

Hasil Uji Durbin Watson

Model Summary ${ }^{b}$

\begin{tabular}{|c|c|c|c|c|c|c|c|c|c|c|}
\hline \multirow[b]{2}{*}{$\begin{array}{l}\text { Mo } \\
\text { del }\end{array}$} & \multirow[b]{2}{*}{$\mathrm{R}$} & \multirow[b]{2}{*}{$\begin{array}{c}\mathrm{R} \\
\text { Squar } \\
\mathrm{e}\end{array}$} & \multirow[b]{2}{*}{$\begin{array}{c}\text { Adjuste } \\
\mathrm{d} R \\
\text { Square }\end{array}$} & \multirow[b]{2}{*}{$\begin{array}{l}\text { Std. } \\
\text { Error of } \\
\text { the } \\
\text { Estimate }\end{array}$} & \multicolumn{5}{|c|}{ Change Statistics } & \multirow[b]{2}{*}{$\begin{array}{l}\text { Durbin- } \\
\text { Watson }\end{array}$} \\
\hline & & & & & $\begin{array}{c}\mathrm{R} \\
\text { Square } \\
\text { Change }\end{array}$ & $\begin{array}{c}F \\
\text { Chang } \\
\mathrm{e}\end{array}$ & df1 & df2 & $\begin{array}{c}\text { Sig. F } \\
\text { Change }\end{array}$ & \\
\hline 1 & $414^{2}$ & .172 & .123 & .68011 & .172 & 3.524 & 3 & 51 & .021 & 2.252 \\
\hline
\end{tabular}

a. Predictors: (Constant), Aktivitas, Likuiditas, Leverage

b. Dependent Variable: Pertumbuhan Laba

Berdasarkan Tabel 1 tingkat nilai signifikansi 0,05 (5\%), dengan n 55 diketahui bahwa dL sebesar 1,4523, dU sebesar 1,6815 dan 4-dU $(4-1,6815)$ sebesar 2,3185. Adapun hasil perhitungan Durbin Watson sebesar 2,252. Nilai ini berada pada daerah $1,6815<2,252<2,3185$ sehingga dapat disimpulkan bahwa data tersebut telah berada pada daerah tidak mempunyai autokorelasi.

\section{Uji Multikolinearitas}

Tabel 2

Hasil Uji Multikolinearitas

\begin{tabular}{|c|c|c|c|c|c|c|}
\hline \multirow{2}{*}{\multicolumn{2}{|c|}{ Model }} & \multicolumn{2}{|c|}{ Unstandardized Coefficients } & \multirow{2}{*}{$\begin{array}{c}\begin{array}{c}\text { Standardized } \\
\text { Coefficients }\end{array} \\
\text { Beta }\end{array}$} & \multirow[b]{2}{*}{$\mathrm{T}$} & \multirow[b]{2}{*}{ Sig. } \\
\hline & & B & Std. Error & & & \\
\hline \multirow[t]{4}{*}{1} & (Constant) & .974 & .394 & & 2.474 & .017 \\
\hline & Likuiditas & -.137 & .069 & -.315 & -1.974 & .054 \\
\hline & Leverage & -.525 & .203 & -.421 & -2.587 & .013 \\
\hline & Aktivitas & .143 & .107 & .174 & 1.328 & .190 \\
\hline
\end{tabular}

a. Dependent Variable: Pertumbuhan Laba

Berdasarkan tabel di atas terlihat bahwa nilai tolerance likuiditas $0,638>0,10$ dan nilai VIF likuiditas 1,568 < 10, nilai tolerance Leverage 0,612 >0,10 dan nilai VIF Leverage yaitu 1,633<10, dan nilai tolerance aktivitas $0,950>0,10$ serta nilai VIF aktivitas yaitu 1,053 < 10. Berdasarkan penjelasan isi tabel tersebut, dapat disimpulkan bahwa tidak terdapat multikolinearitas di antara variabel likuiditas, Leverage dan aktivitas.

\section{Uji Regresi Linear Berganda}

Tabel 3

Ringkasan Hasil Regresi Linear Berganda (SPSS)

\begin{tabular}{|c|c|c|c|c|}
\hline \multicolumn{5}{|c|}{ Dependent Variable: Pertumbuhan Laba $(\mathrm{Y})$} \\
\hline Independent Variable $\left(\mathrm{X}_{\mathrm{i}}\right)$ & Unstandardized Coefficients & $t_{\text {hitung }}$ & $t_{\text {sig }}$ & Keterangan \\
\hline 1. Likuiditas $\left(\mathrm{X}_{1}\right)$ & $-0,137$ & $-1,974$ & 0,054 & Tidak signifikan \\
\hline 2. Leverage $\left(\mathrm{X}_{2}\right)$ & $-0,525$ & $-2,587$ & 0,013 & Tidak \\
\hline 3. Aktivitas $\left(\mathrm{X}_{3}\right)$ & 0,143 & 1,328 & 0,190 & \\
\hline Constant & $=0,017$ & \multicolumn{2}{|c|}{ Multiple $R$} & $=0,414$ \\
\hline Adjusted R Squared & $=0,123$ & \multicolumn{2}{|c|}{$\mathrm{F}_{\text {hitung }}$} & $=3,524$ \\
\hline $\mathrm{F}_{\text {sig }}$ & 0,021 & & & \\
\hline
\end{tabular}




\section{Pembahasan}

\section{Pengaruh Simultan Likuiditas, Leverage, dan Aktivitas Terhadap Pertumbuhan Laba Perusahaan Makanan dan Minuman di Bursa Efek Indonesia}

Rasio likuiditas, leverage dan aktivitas secara simultan memberi pengaruh yang nyata terhadap pertumbuhan laba perusahaan. Ini artinya dalam hal kontribusi secara bersama-sama pertumbuhan laba akan mengalami peningkatan seiring dengan pertambahan kemampuan membayar utang jangka pendek, peningkatan utang dalam membiayai modal dan perputaran aset perusahaan makanan dan minuman. Kasmir (2015:134 ) rasio likuiditas (Curent Ratio) merupakan rasio untuk mengukur kemampuan perusahaan dalam membayar kewajiban jangka pendek atau utang yang segera jatuh tempo pada saat ditagih secara keseluruhan. Hery (2016:162) Rasio leverage atau rasio solvabilitas merupakan rasio yang digunakan untuk mengukur sejauh mana aset perusahaan dibiayai oleh hutang, dalam arti luas rasio solvabilitas atau leverage digunakan untuk mengukur kemampuan perusahaan dalam memenuhi seluruh kewajibannya, baik kewajiban jangka pendek maupun jangka panjangnya.

Aktivitas perusahaan yang makin tinggi yang ditandai oleh tingginya rasio aktivitas akan meningkatkan produktivitas modal untuk menghasilkan laba. Tingkat penjualan yang makin meningkat akan memperbesar rasio aktivitas sehingga perusahaan beroperasi dengan aktivitas tinggi untuk menghasilkan laba yang tinggi pula. Kasmir (2015:187) menyatakan bahwa ketentuan umum perputaran aktiva adalah 2 kali, yaitu setiap 1 Rupiah aktiva dapat menghasilkan 2 Rupiah penjualan. Berdasarkan uraian di atas dan berdasarkan hasil penelitian, dapat disimpulkan bahwa rasio likuiditas, leverage dan aktivitas secara simultan (bersama-sama) berpengaruh signifikan terhadap pertumbuhan laba perusahaan makanan dan minuman periode 2012-2016.

\section{Pengaruh Likuiditas Terhadap Pertumbuhan Laba Perusahaan Makanan Dan Minuman Di Bursa Efek Indonesia}

Berdsarkan hasil penelitian, dapat disimpulkan bahwa rasio likuiditas berpengaruh negatif dan tidak signifikan terhadap pertumbuhan laba perusahaan makanan dan minuman di Bursa Efek Indonesia periode 2012-2016, dengan koefisien sebesar -0,137 dan tingkat signifikansi sebesar 0,054 .

Likuiditas merupakan kemampuan perusahaan untuk memenuhi kewajiban jangka pendek yang harus segera dipenuhi. Perkiraan dalam aset lancar terutama kas, investasi jangka pendek, piutang dan persediaan sering mempengaruhi tingkat likuiditas, dimana semakin besar kas, investasi jangka pendek, persediaan dan piutang berarti semakin tinggi kemampuan perusahaan untuk memenuhi kewajiban yang harus dipenuhi.

Berdasarkan pengamatan, indikator likuiditas yaitu menyangkut aset lancar dan hutang lancar. Untuk meningkatkan jumlah aset lancar terutama jumlah kas, investasi jangka pendek, persediaan serta piutang tersebut perusahaan makanan dan minuman harus mengeluarkan modal yang lebih banyak ditanamkan, sehingga mengakibatkan biaya modal yang ditanggung perusahaan menjadi lebih tinggi dan berdampak menurunkan profitabilitas. 
Disisi lain memang benar perusahaan harus menjaga likuiditas keuangannya atau harta likuidnya dengan tujuan untuk menjaga kepercayaan pihak ketiga yang menanamkan modalnya diperusahaan, dimana para investor memiliki tujuan utama dalam menanamkan modalnya adalah mendapatkan keuntungan yang layak dengan resiko yang rendah, tetapi untuk meningkatkan kemampuaan perusahaan dalam memenuhi kewajiban yang dipenuhi dengan cara meningkatkan jumlah aset lancar justru mengakibatkan semakin besar perusahaan harus mengeluarkan biaya dalam membayar utang jangka pendeknya, sehingga akan berpengaruh terhadap semakin kecilnya profitabilitas yang diperoleh perusahaan. Likuiditas yang ideal adalah 2:1, dimana ketika lebih tinggi ataupun lebih rendah akan mempengaruhi profitabilitas perusahaan.

\section{Pengaruh Leverage Terhadap Pertumbuhan Laba Perusahaan Makanan Dan Minuman Di Bursa Efek Indonesia}

Berdasarkan hasil penelitian dan analisis yang telah dilakukan, leverage berpengaruh negatif dan signifikan terhadap pertumbuhan laba perusahaan makanan dan minuman di Bursa Efek Indonesia periode 2012-2016, dengan koefisien sebesar -0,525 dan tingkat signifikansi sebesar 0.013 .

Pengukuran leverage (Debt to equity ratio) dimaksudkan untuk mengukur seberapa besar modal sendiri untuk menjamin hutang, dengan kata lain seberapa besar perusahaan dibiayai dari hutang. Seluruh perusahaan makanan dan minuman yang diteliti dalam penelitian ini di sebagian investasinya di biayai dari hutang. Itu berarti perusahaan memiliki beban keuangan yang setiap saat harus dipenuhinya. Rasio yang digunakan adalah Debt to equity ratio. Rasio ini berguna untuk mengetahui jumlah dana yang disediakan peminjam (kreditur) dengan pemilik perusahaan, dengan kata lain rasio ini digunakan untuk mengetahui setiap rupiah modal sendiri yang dijadikan jaminan hutang. Hasil penelitian menunjukkan leverage memberikan pengaruh positif dan signifikan terhadap pertumbuhan laba perusahaan makanan dan minuman.

\section{Pengaruh Aktivitas Terhadap Pertumbuhan Laba Perusahaan Makanan dan Minuman di Bursa Efek Indonesia}

Berdasarkan hasil penelitian, rasio aktifitas memiliki koefisien sebesar 0,143 dan tingkat signifikansi sebesar 0,190, yang dapat diartikan bahwa rasio aktivitas berpengaruh positif dan tidak signifikan terhadap pertumbuahan laba perusahaan makanan dan minuman di Bursa Efek Indonesia periode 2012-2016. Penggunaan dana dalam upaya peningkatan operasi perusahaan memerlukan penanganan yang efektif dan efisien. Terutama dalam hal efisiensi pengelolaan keuangan secara umum perusahaan makanan dan minuman sejauh ini dalam kondisi yang buruk. Hal ini tercermin dari rasio aktivitas yang cukup buruk dalam lima tahun terakhir. Rasio aktivitas yang tinggi dapat mempengaruhi pertumbuhan laba, namun pengaruhnya tidak akan terlalu nampak jika tidak dibarengi dengan penggunaan modal yang besar ataupun penggunaan hutang yang besar guna menambah aktiva perusahaan. Dilihat dari indikator rasio aktivitas menunjukkan bahwa salah satu penyebab menurunnya rasio aktivitas adalah adanya penurunan penjualan perusahaan tahun 2012-2016. 
Rudikson

\section{KESIMPULAN DAN SARAN}

\section{Kesimpulan}

1. Rasio likuiditas mempengaruhi pertumbuhan laba perusahaan makanan dan minuman secara negatif dan tidak signifikan, rasio Leverage mempengaruhi pertumbuhan laba secara negatif dan signifikan dan rasio aktivitas mempengaruhi pertumbuhan laba perusahaan makana dan minuman secara positif dan signifikan.

2. Likuiditas, Leverage dan Aktivitas secara simultan (bersama-sama) berpengaruh signifikan terhadap pertumbuhan laba perusahaan makanan dan minuman yang terdaftar di Bursa Efek Indonesia periode 2012-2016.

3. Likuiditas berpengaruh negatif dan tidak signifikan terhadap pertumbuhan laba perusahaan makanan dan minuman yang terdaftar di Bursa Efek Indonesia periode 2012-2016.

4. Leverage berpengaruh negatif dan signifikan terhadap pertumbuhan laba perusahaan makanan dan minuman yang terdaftar di Bursa Efek Indonesia periode 2012-2016.

5. Aktivitas berpengaruh positif dan tidak signifikan terhadap pertumbuhan laba perusahaan makanan dan minuman yang terdaftar di Bursa Efek Indonesia periode 2012-2016.

\section{Saran}

Berdasarkan penelitian ini, maka peneliti dapat memberikan beberapa saran yaitu:

1. Peneliti menyarankan kepada pihak perusahaan agar mengurangi penggunaan hutang dalam membiayai operasional perusahaan, karena hutang harus dibayar pada periode tertentu dan dapat mengurangi laba perusahaan. Perusahaan yang ingin menggunakan hutang untuk menambah biaya operasi perusahaannya, disarankan untuk mengguanakan hutang tersebut seefesien dan seefektif mungkin. Perusahaan juga harus memperhatikan faktor-faktor lain di luar penelitian ini seperti finansial, produksi dan tenaga kerja perusahaan tersebut.

2. Peneliti menyarankan kepada investor agar lebih selektif dan teliti jika ingin menanamkan modalnya pada suatu perusahaan. Berdasarkan penelitian ini Investor dapat melihat bagaimana peran hutang dalam pertmbuhan laba, yang dapat dilihat bahwa DER berpengaruh signifikan terhadap pertumbuhan laba perusahaa. Investor dapat melihat perbandingan jumlah utang dan jumlah aset yang digunakan perusahaan dalam operasional perusahaan.

3. Peneliti selanjutnya disarankan untuk menggunakan obyek penelitian yang lain, guna menambah ragam objek penelitian serta dapat membandingkan penelititian ini dan penelitian yang akan datang.

\section{REFERENSI}

Hery, 2016. Analisis Laporan Keuangan, Jakarta: PT. Gramedia Widiasarana Indonesia.

Indrianto, Nur dan Bambang Supomo, 2009. Metodologi Penelitian Bisnis Untuk Akuntansi dan Manajemen, Bandung: BPFE.

Kasmir, 2015. Aanalisis Laporan Keuangan, Cetakan ke-8, Jakarta: PT. Raja Grafindo Persada.

Mahaputra, I Nyoman Kusuma Adyana, 2012. Pengaruh Rasio-Rasio Keuangan Terhadap Pertumbuhan Laba Pada Perusahaan Manufaktur Yang Terdaftar Di BEI, Jurnal Akuntansi Dan Bisnis, 7 (2), 243-254.

Santoso, S, 2000. Buku Latihan SPSS Statistik Parametrik, Jakarta: Gramedia.

Sugiyono. 2013. Statistika Untuk Penelitian. Bandung: Alfabeta.

Sutrisno, 2013. Manajemen Keuangan: Teori Konsep dan Aplikasi, Cetakan Ke Sembilan, Yokyakarta: Ekonisia.

Warsidi dan Pramuka, 2000. Pemahaman Ekonomi Umum, , Jakarta: PT. Gramedia Pustaka Umum. www.idx.co.id 